\title{
Peoples' Solutions to Food Systems Transformation in Asia and the Pacific
}

\author{
Tammi Jonas ${ }^{1}$ \\ Published online: 11 October 2021 \\ (c) Society for International Development 2021
}

\begin{abstract}
Peasants and fisherfolk around the world, supported by academic and NGO allies, have denounced the UN Food Systems Summit for its overt corporate capture instead of what should have been a democratic process with strong grassroots participation from social movements. Across the globe, food sovereignty activists and allies have organized autonomous counter-mobilizations, including in Asia and the Pacific, to share what a radical transformation of our food and agriculture systems should really look like. This article shares the peoples' proposals and current grassroots activities towards radical food systems transformation that were shared at the Asia Pacific peoples' regional dialogue.
\end{abstract}

Keywords Food sovereignty $\cdot$ Agroecology $\cdot$ Blue Justice $\cdot$ Solidarity $\cdot$ Collectivization

\section{The 2021 UN Food Systems Summit and the WEF}

With its political roots established in the mid-1990s in the fertile soils of La Vía Campesina (LVC), food sovereignty was launched into public political discourse at the 1996 World Food Summit in Rome (Alonso-Fradejas et al. 2015). In the words of McMichael (2015: 934), 'food sovereignty emerged as the antithesis of the corporate food regime and its (unrealized) claims for "food security" via the free trade rules of the World Trade Organization (WTO).' Twenty-five years later, the fight continues.

The 2021 UN Food Systems Summit (UNFSS) was co-opted from its inception. The World Economic Forum (WEF), using the UN as its mouthpiece and the UNFSS as its megaphone, set out to sell us the solutions to the multiple crises its members have created in the world. What should have been a democratic, grassroots peoples' process to design, implement, and promote a radical transformation of the world's food systems was co-opted by multinational corporations into a marketplace of ideas for sale to the highest bidder.

Tammi Jonas

tammois@gmail.com

1 Australian Food Sovereignty Alliance, Eganstown, Australia
As the shift from multilateralism to multi-stakeholderism has been accelerating across UN platforms, corporations have gained increasing control of the narratives for change. Failing to take action against their own excesses in spite of decades of warning, the multi-stakeholder dialogues hosted by the powerful elite have brought us five 'action areas'. Instead of food sovereignty, they would sell us food security. Their inability to co-opt the science, practices, and social movement inherent in agroecology leads them to 'boost nature-based solutions', ensuring a boost in profits for multinationals instead of a commitment to ending the degrading practices of industrial agriculture. Nature-based solutions include carbon credits for offsets-essentially a free pass for the most polluting industries to buy their way to 'net zero'. The action areas promote 'equitable livelihoods', which we take to mean they want to employ us in their fields and factories rather than assure us our right livelihoods with secure tenure. Next, they propose to teach $u s$-some of the world's most enduring, resourceful, and sustainable custodians of land, rivers, and sea-resilience. And finally, the multinationals are here to attract investment in their false solutions, selling off more land and resources, while guaranteeing their influence over the structures that govern them.

Rather than considering the root causes of the failures in our food system, the 'Summit's overall emphasis has been on how to "boost production" sustainably through new technologies' (Fakhri 2021). We do not need to produce more food, we need to ensure its production is democratically 
determined, governed, and distributed to ensure equal access to all. To further underscore the willfulness with which Summit leaders have ignored the real causes of hunger, disease, and ecological devastation wrought by the current industrial food system, the pre-Summit program ${ }^{1}$ scarcely mentioned the COVID-19 pandemic and its impact on local, national, regional, and global food supply chains.

\section{The Peoples' Counter-Mobilizations in Asia and The Pacific}

In July 2021, smallholders from across Asia and the Pacific came together as part of the Peoples' Autonomous Response to the UN Food Systems Summit to discuss our proposals for a radical transformation of the food system. Our solutions focused on the following:

- The importance of agency and autonomy of Indigenous Peoples, peasants, and fisherfolk in solving the problems we face on the ground is fundamental-embedded in place and determined democratically.

- We must continue to form stronger alliances across countries and the region to fight corporate control of the food system.

- We must continue building producer-owned cooperatives for production, processing, and distribution.

- We need secure land tenure and access to natural resources, and we resolved to strengthen the struggle against land grabbing.

- We need a radical paradigm shift away from Blue Economy to Blue Justice in fisheries, which is crucial for climate justice, encompassing economic, social, and environmental justice.

- We must promote and scale out agroecology as a science, a set of practices, and a social movement, as agroecology is central to the genuinely radical transformation of the food system we need (Méndez et al. 2013).

We will now share initiatives and hopeful signs of progress in our region that demonstrate the difference between the corporate and neoliberal discourses of 'aid' and 'food security' intrinsic to the UNFSS so-called dialogues and solutions, and our grassroots, social movements' discourses of 'agency' and 'food sovereignty' in action.

\footnotetext{
1 https://www.un.org/sites/un2.un.org/files/pre-summit_final_progr am_july_23_2021.pdf accessed 2 October 2021.
}

\section{Right to Participate in Decision-making}

While globally smallholders' involvement in decision making processes continues to be limited and often actively opposed by powerful interests, food sovereignty has been enshrined in the constitution of Nepal since 2007, a remarkable achievement for the All Nepal Peasants' Federation (ANFPA) and peasants' movements worldwide. More recently, we have had some good news in Australia, where the Australian Food Sovereignty Alliance (AFSA) reports strengthening relationships with state governments that led to significant legislative reforms in 2018 of land use provisions that better enable the flourishing of small-scale, pastured livestock farming systems. When undertaking further work that has potential impacts on smallholders, the agriculture department in the state of Victoria now actively seeks input from AFSA and its members.

\section{Building Solidarity}

Regional alliances are being forged and strengthened to no small degree through collective organizing against the UNFSS, with regional and global meetings, and national counter-mobilizations that share the messages of organizations within and outside our countries, and cross promoted and attended by many activists across our region and the world. The virtual modalities required by travel restrictions due to the ongoing pandemic have caused much inequity in civil society's (and many parties in the Global South) capacity to engage in ongoing UN processes such as the Convention on Biological Diversity's (CBD) work on the post-2020 Global Biodiversity Framework, or the International Treaty for Plant Genetic Resources for Food and Agriculture (ITPGRFA) meetings on Article 9: Farmer's Rights. And yet we applied ourselves to the problems caused by working across time zones, staggering timings of meetings and hosting regional meetings to gather movement input that could be taken to global meetings hosted at unfriendly hours for many in Asia and the Pacific.

\section{Collectivizing the Means of Production, Processing, and Distribution}

We are witnessing a growth of farmers' cooperatives servicing territorial markets across the region as producers work together to regain local control of value chain infrastructure. There are cooperatively owned and operated rice mills in Cambodia, organic produce collectives in South Korea, and dairy cooperatives in South Asia. In Australia, a fledgling movement towards cooperatively owned abattoirs has emerged in the face of ever more concentrated ownership of slaughter facilities by multinationals like JBS. In the 
Philippines, FARMCOOP was established 30 years ago to use 'the country's land reform law to become the owners of the plantations where they had labored for generations' (Bacon 2020). [...] At the same time, FARMCOOP has called for alternatives to the unsustainable and environmentally destructive farming technology perpetuated by those corporations', and increasingly shifted its banana production from chemical-intensive farming to organic practices. Once its political strategies were established and succeeding in bringing peasants and other rural workers out of poverty, FARMCOOP reached out to Indigenous Peoples in Mindanao to help them establish their own cooperatives that bring together local traditions with organic agriculture.

\section{Responsible Governance of Tenure of Land}

After decades of fighting for secure and equitable land tenure, the Indonesian Peasant Union (SPI) and other agrarian reform movements were invited by President Joko Widodo to discuss evaluating the implementation of agrarian reform in late 2020. The President of the Republic of Indonesia then directed his government to accelerate the resolution of agrarian conflicts. While land grabbing remains one of the most significant threats to food sovereignty in our region, strengthening our organizations and building further alliances across the social movements can help fight against it, and the emergence of the Land Matrix public database on land deals is a step in the right direction. ${ }^{2}$. In Timor Leste, UNAER has one of the strongest political voices for farmers and is an active participant in MOKATIL (Timor Leste's La Vía Campesina representative). UNAER's fight for land reform was enshrined into law in 2017, 'allowing Timorese farmers to obtain legal rights to farm their own land following centuries of colonisation, forced labour for corporations and land grabbing. ${ }^{3}$

\section{Blue Economy vs Blue Justice}

Asia and the Pacific region are the largest producers of fish at 61 percent of the world's catch (FAO 2017). A 'gamechanging solution' under the UNFSS 'Action Area 2: Boost Nature-Based Solutions of Production' calls for an Alliance of Blue Foods, acknowledging the importance of fisheries to livelihoods and nutrition for much of the world. However, global dialogues around sustainable fisheries and aquaculture to date typically focus on Blue Economies- the need to increase 'sustainable' harvests from fresh and marine fisheries, and to radically increase the volume of production from

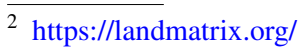

3 https://www.apheda.org.au/sustainable-farming-timor-leste/ accessed 2 October 2021
}

intensive aquaculture for food and nutrition security in the Global South. Civil society organizations including La Vía Campesina and the International Planning Committee for Food Sovereignty (IPC) have for many years rejected the proposals to boost production from over-fished inland and marine waters and intensive aquaculture, highlighting the devastation already wrought to terrestrial and marine ecosystems by intensive livestock production.

In contrast, the National Fisheries Solidarity Organization (NAFSO) in Sri Lanka and other representatives for fisherfolk globally are demanding 'Blue Justice,' 'which ensures food sovereignty through Social Justice, Gender equity, Environmental Justice, Eco System Services, Economic benefits, Tenure Access and empowering Fishing communities those depending on the Aquatic resources'. ${ }^{4}$ Blue Justice is a much-needed counter-narrative to the pro-growth agenda of multinationals that dominates global fisheries governance. 'Blue Justice Alert: An Interactive Platform for Securing Small Scale Fisheries' ${ }^{5}$ is a welcome development supporting the efforts of the world's fisherfolk to protect lives and livelihoods by providing a platform for horizontal knowledge sharing about the challenges they face and the ways they are addressing them.

\section{Agroecology}

Economic, political, knowledge, and cultural lock-ins can limit the ability of farmers to shift to agroecology. For example, Iles (2020) proposes, agroecology tends to be delegitimized by actor networks whose theories of change stymie such transitions. He asserts:

Strong beliefs among scientist, industry, and government elites in the power of science and technology to overcome climate constraints are leading to agroecology being ignored (Iles 2020: 5).

Iles also explains that some of the implications of neoliberal agriculture policies for agroecology include: 'Weak farmer resources for adopting agroecological practices; demoralized and eroding rural communities; investment in export support instead of environmental support' (Iles 2020: 5). In turn, summarizing work by Mier y Terán Giménez Cacho and colleagues, Iles describes enabling dynamics for an agroecological transition, including 'crises, coalescing social organization, effective agroecological practices, external allies, and favorable policies.' (Iles 2020: 7). All of these dynamics are currently coalescing with a global pandemic, a strengthening

\footnotetext{
${ }^{4}$ https://www.facebook.com/nafsosl/posts/2878793005769457 accessed 2 October 2021.

5 http://toobigtoignore.net/blue-justice-alert-project/ accessed 2
} October 2021. 
and increasingly mobilized global food sovereignty movement, and the emergence of more agroecology schools following a pedagogy of horizontal knowledge exchanges.

Across our region, our peasants' organizations are facilitating farmer-to-farmer knowledge exchanges in field schools and workshops. In Timor Leste, MOKATIL's peasant organization members such as UNAER train farmers in leadership and agroecology following Vía Campesina/Paolo Freire methodologies. SPI facilitates School of Agroecology and Seeds field days, and in 2016, hosted an exchange with the Korean Women Peasants Association (KWPA) in Indonesia for cross-cultural knowledge sharing of agroecology, and the struggle for the right to peasants' seeds. At the Amritabhoomi Centre in the southern State of Karnataka, India, La Vía Campesina hosts agroecology schools to support the growth of young farmers, and in Australia, AFSA commenced Agroecology Workshops hosted by farms in diverse geographical settings across the country in 2021.

From the global to the local-I would like to finish by sharing the deeply grounded agroecological work I do here on my farm with my husband and our community. On Dja Dja Wurrung country in the central highlands of Victoria, we raise heritage breed Large Black pigs and Speckleline cattle on pasture, and transform carcasses into a range of fresh cuts, smallgoods, and charcuterie in our on-farm butcher's shop. Bones that remain after we have processed them into broth are pyrolized into bonechar, which is then activated in barrels of microbially-rich biofertilizer and used to grow our small commercial crop of heritage-variety garlic and a diverse range of vegetables to feed the farm community. Like millions of other smallholders around the world, we are maintaining biodiversity at the genetic, species, and ecosystem levels. Living a life made in common with Nature, we conserve and sustainably use the biodiversity in our care, and as non-Indigenous Australians, we have chosen to share the benefits of our use with the First Peoples by paying one percent of our income to a local Indigenous organization.

\section{Call to Action}

Across Asia and the Pacific, there are many more empirical examples of smallholders and their communities doing critical work to care for country, draw down carbon, and collectively organize against corporate power in the food system that continues to erode the health and well-being of land and communities everywhere. Agroecology fundamentally aims to promote the deep ecological, social, and economic knowledge of Indigenous Peoples, peasants, fisherfolk, and other small-scale food producers and custodians of land and water. It puts decision making power back in the hands of Indigenous Peoples and peasants and local communities. If the organizers of the UNFSS were genuine in their claim to a 'People's Summit', the People would have turned up. Instead, you'll find us organizing and participating in the People's Autonomous Response to the UN Food Systems Summit. ${ }^{6}$

Viva La Vía Campesina!

\section{References}

Alonso-Fradejas, Alberto, Saturnino M. Borras, Todd Holmes, Eric Holt-Giménez, and Martha Jane Robbins. 2015. Food sovereignty: convergence and contradictions, conditions and challenges. Third World Quarterly 36 (3): 431-448.

Bacon, David. 2020. Philippine banana farmers: their cooperatives and struggle for land reform and sustainable agriculture, food first, https://foodfirst.org/publication/philippine-banana-farmers-theircooperatives-and-struggle-for-land-reform-and-sustainable-agric ulture/ accessed 14 September 2021.

Fakhri, Michael. 2021. Interim report of the Special Rapporteur on the right to food, A/76/237, United Nations General Assembly. https://www.ohchr.org/Documents/Issues/Food/Policy_brief_ 20210819.pdf.

FAO, 2017 Status and potential of fisheries in Asia and the Pacific 2016, APFIC:EXCO/17/INF 05b, http://www.fao.org/3/I9947EN/ i9947en.pdf accessed 10 September 2021.

Iles, Alastair. 2020. Can Australia transition to an agroecological future? Agroecology and Sustainable Food Systems 45 (1): 3-41. https://doi.org/10.1080/21683565.2020.1780537.

McMichael, Philip. 2015. A comment on Henry Bernstein's way with peasants, and food sovereignty. Journal of Peasant Studies 42 (1): 193-204. https://doi.org/10.1080/03066150.2014.936853.

Méndez, Ernesto V., Christopher M. Bacon, and Roseann Cohen. 2013. Agroecology as a transdisciplinary, participatory, and action-oriented approach. Agroecology and Sustainable Food Systems 37 (1): 3-18. https://doi.org/10.1080/10440046.2012.736926.

Publisher's Note Springer Nature remains neutral with regard to jurisdictional claims in published maps and institutional affiliations.

\footnotetext{
$\overline{6}$ https://www.foodsystems4people.org/ accessed 2 October 2021.
} 